\title{
Effect of salt and organic acid on storage quality of minimally processed Indian spinach
}

\author{
$\bowtie$ Raju Ahmmed ${ }^{1}$, Farjana Akter Sukhi², Fardana Binte Zaman², Shimul Das ${ }^{2}$, Md. Fakhrul Hasan ${ }^{3}$, \\ Md. Junaeid Khan ${ }^{1}$ \\ ${ }^{1}$ Department of Food Engineering, Dhaka University of Engineering and Technology, Gazipur, Bangladesh. \\ ${ }^{2}$ Department of Food Technology and Engineering, Patuakhali Science and Technology University, Dumki, Patuakhali, \\ Bangladesh. \\ ${ }^{3}$ Department of Horticulture, Patuakhali Science and Technology University, Dumki, Patuakhali, Bangladesh
}

\begin{tabular}{|c|c|}
\hline ARTICLE INFO & Abstract \\
\hline $\begin{array}{l}\text { Accepted : } 15 \text { February } 2019 \\
\text { Published: } 31 \text { March } 2019\end{array}$ & \multirow{3}{*}{ 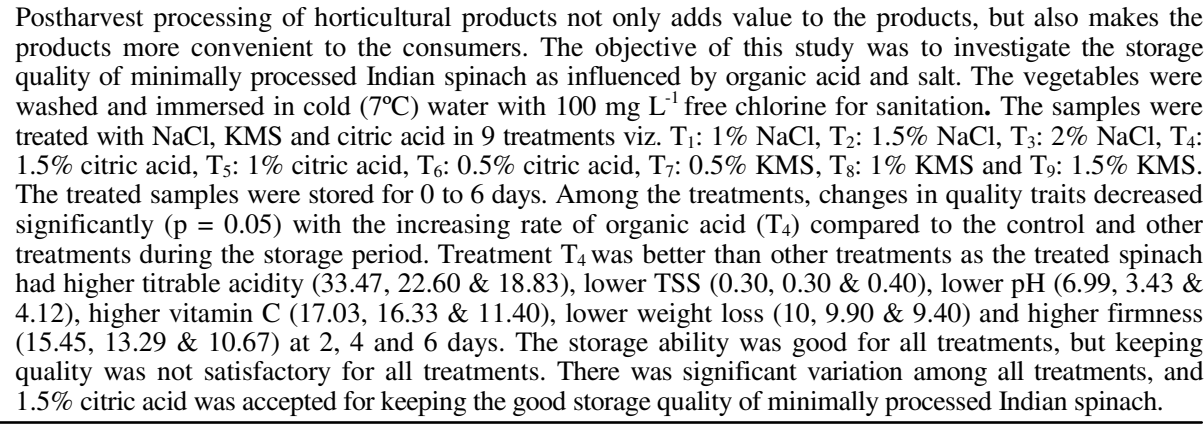 } \\
\hline $\begin{array}{l}\text { Keywords: } \\
\text { Spinach, Processing, } \mathrm{NaCl}, \mathrm{KMS}, \\
\text { Citric acid, Quality }\end{array}$ & \\
\hline $\begin{array}{l}\text { Raju Ahmmed } \\
\text { 凶: rahmmed@duet.ac.bd }\end{array}$ & \\
\hline
\end{tabular}

(c) (i)

(C2019 by authors and BAURES. This work is licensed under the Creative Commons Attribution International License (CC By 4.0).

\section{Introduction}

In Bangladesh, there are still significant losses of agricultural products due to inadequate use of technology during cultivation, handling, storage, and preservation. An alternative technology to minimize post-harvest losses is the minimal processing of vegetables (Chitarra, 1999). The demand for minimally processed vegetables has promoted an increase in the nutritional quality and safety of a variety of food products. In Bangladesh, total area of Indian spinach cultivation is about 10217 hectares with the production of 78665 metric tons in 2015-2016 (BBS, 2016). Minimal processing is an integrated approach, where raw materials handling, processing, packaging, and distribution must all be properly considered to make shelf-life extension possible and offer consumer with high nutrition. Being living materials, fresh-cut produce can modify the atmosphere in their packages as a result of respiratory $\mathrm{O}_{2}$ consumption and $\mathrm{CO}_{2}$ evolution (Pirovani et al., 1998). Major problems associated with fresh-cut vegetables are the development of strong offodors and decay, discoloration, and tissue softening (Zagory and Kader, 1988). The physical damage accrued during minimal processing, especially with wounding, causes disruption of the cellular membrane, putting enzymes and their substrates in direct contact, which

\section{Cite this article}

Ahmmed, R., Sukhi, F.A., Zaman, F.B., Das, S., Hasan, M.F. and Khan, M.J. 2019. Effect of salt and organic acid on storage quality of minimally processed Indian spinach. Journal of Bangladesh Agricultural University, 17(1): 99-104. https://doi.org/10.3329/jbau.v17i1.40670 accelerates the loss of quality and storage life. Unit operations applied in the commercial production of minimally processed vegetables usually include cleaning, peeling, cutting, washing, and packaging. To increase the shelf life of vegetables, different types of synthetic chemicals are used commercially that are harmful for human beings. But organic substances and safe salts can be the alternative of hazardous synthetic chemicals.

To overcome the undesirable changes, cut produce are immersed in different treatment solutions at the final stage of handling operations. Compounds such as ascorbic and citric acids, sodium meta bisulphite and sodium chloride have been utilized in many parts of the world as suitable preservatives for maintaining quality of minimally processed produce such as potato, spinach and apple (Ahvenainen, 1996; Cortez-Vega et al., 2008).

At present, Indian spinach is selected to minimally process due to its rich nutritional contents and higher use in our daily life for preparing of variety of foods. Moreover, nutrients like iron, calcium and vitamin $\mathrm{K}$ are present in higher concentrations due to which it becomes more beneficial against some serious health problems like anaemia, haemorrhage and clotting dysfunction and to maintain electrolytes balance in our body (Raheem $e t$ 
al., 2015). Now a day's, people, especially the office going ladies, are becoming busy for different activities and they have no enough time to process vegetables by washing, cutting, peeling for ready to eat. Again, sometimes the quality of those vegetables is not so satisfactory for health; it may not be fresh, mature or other problems as well. Due to those reasons, people lose interest to take vegetables. This kind of problems can be overcome by providing minimally processed vegetables. Therefore, the present study was conducted to evaluate the physical and chemical properties of minimally processed Indian spinach, to evaluate the effects of $\mathrm{NaCl}$, KMS and Citric acid on minimally processed Indian spinach, and to study the hygienic quality of minimally processed Indian spinach.

\section{Materials and Methods}

\section{Sample collection}

Indian spinach was collected directly from the farmers' fields of Dumki, Patuakhali at the optimum stage of maturity. Sample of matured and freshly harvested Indian spinach was carried at the Horticultural Laboratory, Patuakhali Science and Technology University (PSTU).

\section{Sample processing}

The sanitation of the process was ensured by personal hygiene and the use of aprons and gloves. All the utensils used were previously sanitized in $200 \mathrm{mgL}^{-1}$ free chlorine. The sample was washed in fresh water, cut with sharp stainless-steel knives and immersed in cold water $\left(7^{\circ} \mathrm{C}\right)$ for $15 \mathrm{~min}$. Indian spinach was cut into 3$\mathrm{mm}$ thick slices having round shape using a knife. These were then immersed in cold water $\left(7^{\circ} \mathrm{C}\right)$ with $100 \mathrm{mgL}^{-1}$ free chlorine at $\mathrm{pH} 7.0$ for $15 \mathrm{~min}$ for sanitation. After completing the cleaning process, sliced samples were dipped in various postharvest treatments. Then the samples were put into polyethylene bags. Bags with $50 \mathrm{~g}$ sliced samples were sealed under different treatments.

\section{Treatments and experimental design}

Nine post-harvest treatments, including a control, were used for the present study. The treatments were $T_{0}$ : Control (untreated Indian spinach), $\mathrm{T}_{1}: 1 \% \mathrm{NaCl}, \mathrm{T}_{2}$ : $1.5 \% \mathrm{NaCl}, \mathrm{T}_{3}: 2 \% \mathrm{NaCl}, \mathrm{T}_{4}: 1.5 \%$ Citric acid, $\mathrm{T}_{5}: 1 \%$ Citric acid, $\mathrm{T}_{6}: 0.5 \%$ Citric acid, $\mathrm{T}_{7}: 0.5 \% \mathrm{KMS}, \mathrm{T}_{8}: 1 \%$ KMS, and $\mathrm{T}_{9}: 1.5 \%$ KMS. The experiment was laid out in the Completely Randomized Design (CRD) with 3 replications.

\subsection{Parameters}

Two physical changes: weight loss and firmness, and four chemical changes such as Total Soluble Solids (TSS), Titratable Acidity (TA), Vitamin $\mathrm{C}$ and $\mathrm{pH}$ were measured.

\section{Preparation of treatments}

1\% NaCl: Ten (10) $\mathrm{g} \mathrm{NaCl}$ was added to $100 \mathrm{ml}$ distilled water and then vortexing was done for proper mixing of solution. Thus, $1 \% \mathrm{NaCl}$ solution was prepared. Again $1.5 \%$ and $2 \% \mathrm{NaCl}$ were also prepared in the same way according to concentration.
1.5\% Citric acid: Fifteen (15) g citric acid was added to $100 \mathrm{ml}$ distilled water and then vortexing was done for proper mixing of solution. Thus, $1.5 \%$ citric acid solution was prepared. Again, $1 \%$ and $0.5 \%$ citric acids were also prepared in the same way according to concentration.

1.5\% KMS: Fifteen (15) g KMS was added to $100 \mathrm{ml}$ distilled water and then vortexing was done for proper mixing of solution. Thus, $1.5 \%$ KMS solution was prepared. Again, $1 \%$ and $0.5 \%$ KMS were also prepared in the same way according to concentration.

\section{Application of postharvest treatments}

Every sample was kept separately in a tray. Thereafter, the individual sample was treated by $\mathrm{NaCl}$, KMS and citric acid of different concentrations for $5 \mathrm{~min}$. After completing the treatments, all the samples were kept in air-tight polyethylene bags as per treatments of the study and then stored in refrigerator under low temperature. Data were recorded at 0,2, 4 and 6 days after storage as per treatments.

\section{Physicochemical analysis}

Firmness: Firmness was measured by using the Magness-Taylorpressure testers (Model GY-802). The firmness testing machine was equipped with a 4-mm diameter cylindrical probe that was penetrated in the normal direction. The reading was taken for each sample at collar, middle and end points according to Hassan (2006).

Weight loss: Weights of packages with sample slices were measured using an electronic balance (Sartorius BP $6100, \mathrm{R} \& \mathrm{M}$ marketing, UK). The difference in the weight was expressed as gram of weight loss of the samples (Anthony et al., 2003).

Titratable acidity: Titratable acidity of the filtered sample was measured with sodium hydroxide at $0.01 \mathrm{~N}$ (the results for the Indian spinach was expressed in \% of citric acids) (AOAC, 1995).

pH: $\mathrm{pH}$ was determined in the triturated sample by a digital electronic $\mathrm{pH}$ meter. Before measurement, the $\mathrm{pH}$ meter was standardized with a buffer solution as described by (Ranganna, 1994).

TSS: Ten (10) g sample of Indian spinach was blended with distilled water $(40 \mathrm{ml})$ in a homogenizer (Black \& Decker, BX 250, Hunt Valley, USA) for 2 min. The homogenate was filtered through a muslin cloth, and few drops of the filtrate were used to measure TSS using a hand-held Refractometer (BOE-32195).

Vitamin C: The content of vitamin $\mathrm{C}$ was determined with Tillman's reagent (2.6 dichlorophenolindophenol) titration until a slightly pink coloration was stabilized for $15 \mathrm{~s}$. The results were expressed in mg of ascorbic acid per $10 \mathrm{~g}$ of sample (Pregnolatto and Pregnolatto, 1985).

\section{Data Analysis}

Statistical analyses were done using Mixed-model analyses of variance (ANOVAs). Mean values of the samples were compared using Fisher's Least Significant Difference (LSD) test among the treatments. 


\section{Results and Discussion}

\section{Effect of treatments on weight-loss}

Weight-loss values for minimally processed Indian spinach showed differences among treatments. The weight-loss values at different days decreased with the increasing storage period (Fig. 1). There was significant difference among all treatments. At 2, 4, and 6 days $\mathrm{T}_{4}$ attained the highest score $(10 \mathrm{~g}, 9.90 \mathrm{~g}$ and $9.40 \mathrm{~g}$, respectively); the difference was significant $(\mathrm{p}=0.05)$. At 2 and 4 days, $\mathrm{T}_{0}$ got the lowest score $(9.10 \mathrm{~g}, 8.21 \mathrm{~g})$ and at 6 days $T_{9}$ provided the lowest score $(7.57 \mathrm{~g})$. Water loss results in weight loss, wilting and shrivelling. At the time of harvest, the water content of vegetables is very high and has a fresh appearance and crisp texture. Harvesting removes the plant part from its water supply and the product begins to lose weight. This loss of water has an immediate economic effect in that it reduces saleable weight. Maximum permissible water loss for a number of Indian spinach is 3\% (Kays and Paull, 2004). Any type of package slowed water loss when compared to using no package. In this study, water loss rate was low in $\mathrm{T}_{4}$. Although we used polythene bag, the slight changes occurred due to small pores in the bags. So, $\mathrm{T}_{4}$ treatment is considered more acceptable than other treatments for long storage period and better quality of minimally processed Indian spinach.

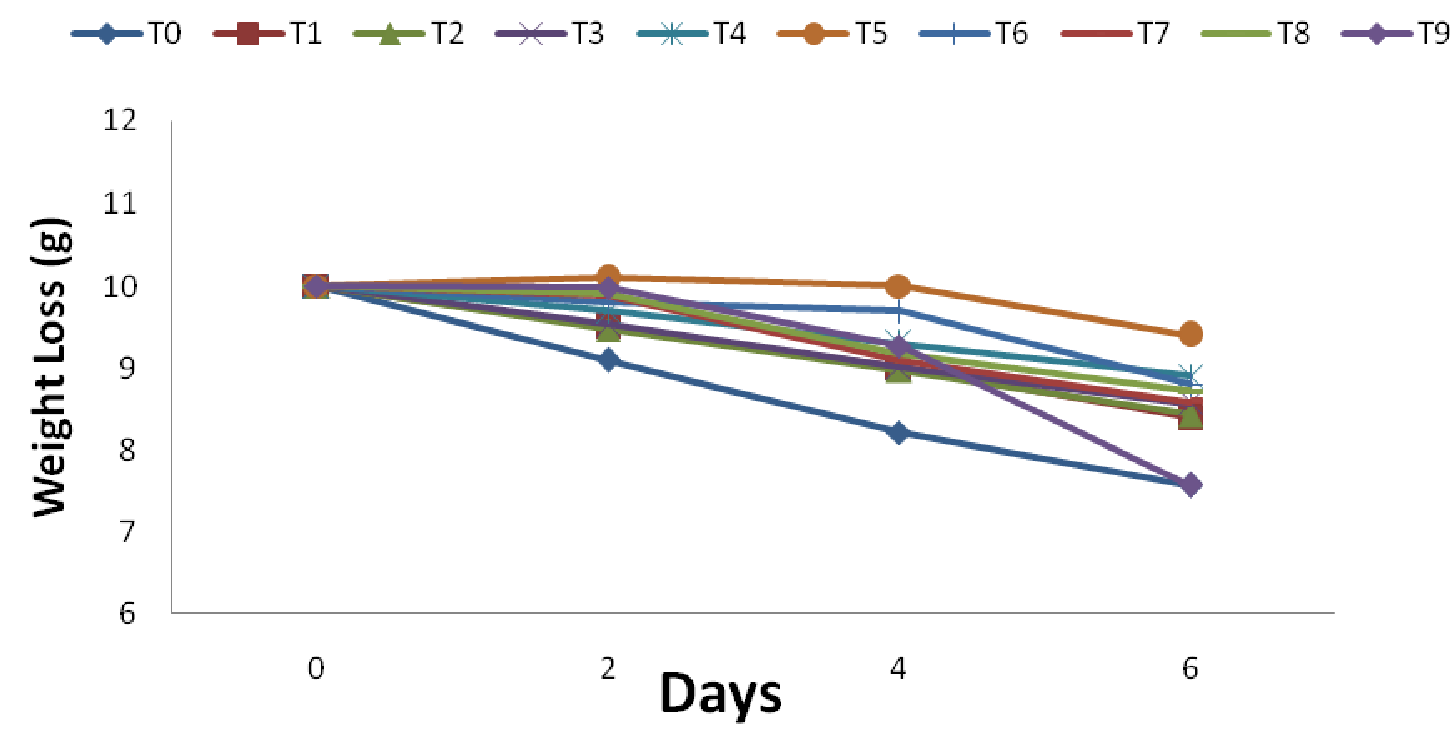

Fig. 1. Variation of weight-loss on minimally processed Indian spinach with storage time under different treatments

\section{Effect of treatments on firmness}

In the minimally processed Indian spinach, the average values found for firmness ranged from 7.77 to $15.45 \mathrm{~kg}$ $\mathrm{cm}^{-2}$ during different storage periods and among treatments (Tables 1 and 2). The firmness at different days of the minimally processed Indian spinach decreased with increasing storage period. At 2 days, $\mathrm{T}_{4}$ attained the highest score (15.45), but treatment $\mathrm{T}_{9}$ got the lowest score (12.01). At 4 days, treatment $\mathrm{T}_{4}$ attained the highest score (13.29) and treatment $\mathrm{T}_{6}$ got the lowest score (10.33). The highest score at 6 days was gained by the treatment $\mathrm{T}_{4}(10.67)$ and treatment $\mathrm{T}_{9}$ gained the lowest score (7.77). According to LSD values at 5\% significant level, the difference was significant among all treatments (Tables 1 and 2).

Firmness is an important attribute that determines the acceptance or rejection of minimally processed produce by consumers. According to Ekanayake (2014), minimally processed immature jack fruit pre-treated with citric acid and ascorbic acid showed a slight decrease in firmness after 7 days of storage at $5-7^{0} \mathrm{C}$. Textures of vegetables lose as moisture decreases. According to Ben-Yehoshuaet al., (2005) if leafy vegetables lose more than $3 \%$ of the original fresh weight, they become unsalable. The texture of vegetables' vegetative tissue is dependent on the cell wall. The decrease in firmness with storage may be due to the destruction of parenchymal cells, leading to softening of the plant material. In our study, a slight decrease in firmness was observed in treatment $\mathrm{T}_{4}$; this is desirable for better quality of minimally processed Indian spinach than other treatment including the control (Table 1).

\section{Effect of treatments on Total Soluble Solids (TSS)}

In the minimally processed Indian spinach, the average values found for TSS ranged from $0.3^{0}$ Brix to $0.7^{0}$ Brix during different storage periods and among treatments (Tables 1 and 2). The total soluble solids at different days increased with increasing storage period. At 2 days, $\mathrm{T}_{7}$ attained the highest score $(0.60)$, but treatments $\mathrm{T}_{5}$ and $\mathrm{T}_{4}$ got the lowest score (0.30). At 4 days, treatment $\mathrm{T}_{7}$ attained the highest score $(0.70)$ and treatment $\mathrm{T}_{4}$ got the lowest score $(0.30)$. The highest score at 6 days was gained by the treatment $\mathrm{T}_{8}(0.70)$ and treatment $\mathrm{T}_{4}$ gained the lowest score (0.40) (Table 2). According LSD values at $\mathrm{p}=0.05$, there was no significant difference among all treatments (Table 1 and 2). Vegetables contain many compounds, which are soluble in water 
such as sugars, acids, vitamin $\mathrm{C}$ and amino acids. These soluble compounds form the soluble solid content of the vegetables. Increase in TSS content reflects hydrolysis of starch into sugars and makes vegetable sweeter. But, the treatments impede the process and keep accurate quality of vegetables and make them acceptable to the consumer. The lower value of TSS means lower content of sugar and better quality of vegetables. So, treatment $\mathrm{T}_{4}$ was more acceptable than the other treatments for TSS.

\section{Effect of treatments on Titrable Acidity (TA)}

The contents of titratable acidity, TA, affected by the storage period and presented statistical differences among treatments for Indian spinach. The average values found for TA ranged from $12.33 \%$ to $33.47 \%$ during different storage periods and among treatments (Tables 1 and 2). Titratable acidity at different days decreased with increasing storage period. At 2 days, $T_{4}$ attained the highest score (33.47) but treatment $\mathrm{T}_{0}$ got the lowest score (16.07) (Table 1). At 4 days, treatment $\mathrm{T}_{4}$ attained the highest score (22.60) and treatment $\mathrm{T}_{0}$ got the lowest score (14.30). The highest score at 6 days was gained by the treatment $T_{4}(18.83)$ and treatment $T_{0}$ gained the lowest score (13.83) (Table 2). According to LSD values at $\mathrm{p}=0.05$, the difference was significant among all treatments (Tables 1 and 2). There was a significant decline in TA with storage periods due to the effect of treatments.

Titrable Acidity describes simple estimate of the total acid content of food. The amount of organic acids in food directly affects the food flavour, color, stability, and the level of quality. When organic acid content increases, TA values increase that makes minimally processed vegetables more acidic and reduces flavour, texture and quality.
Girardi et al., (2005) showed that decline of titratable acidity during storage is inevitable, but citric acid treatment can help to better retain titratable acidity. In our research, $1.5 \%$ citric acid treatment $\left(\mathrm{T}_{4}\right)$ hold high content of TA. According to Economos and Clay (1999), citrus vegetables are a rich source of vitamins, minerals and dietary fiber that are essential for normal growth and development and overall nutritional well-being. So, $\mathrm{T}_{4}$ was considered more acceptable for long storage period and good quality of Indian spinach, but it slightly reduces flavour and affects tastes.

\section{Effect of treatments on Vitamin C}

The vitamin $\mathrm{C}$ contents of the samples of minimally processed Indian spinach presented differences among treatments (Tables 1 and 2). Vitamin $\mathrm{C}$ at different days decreased with increasing storage periods. According to LSD values at $\mathrm{p}=0.05$, the difference was significant among all treatments (Tables 1 and 2).At 2 days, $\mathrm{T}_{4}$ attained the highest score (17.03) but treatment $\mathrm{T}_{0}$ got the lowest score (11.00) (Table 1). At 4 days, treatment $\mathrm{T}_{4}$ attained the highest score (16.33) and treatment $\mathrm{T}_{0}$ got the lowest score (10.70). The highest score at 6 days was gained by the treatment $T_{4}(11.40)$ and treatment $T_{0}$ gained the lowest score (3.60) (Table 2).

Vitamin C levels oscillated with a slight decrease during the period of storage in all treatments carried out (Table 1). Similar results were found by (Benedetti et al., 2002) in sliced green peppers packed in expanded polystyrene trays and wrapped in PVC (polyvinyl chloride) film stored at $5^{\circ} \mathrm{C}$ for 10 days. Vitamin $\mathrm{C}$ was lost during minimal processing through cutting during storage. Chemical treatments retained the nutritional quality as well as vitamin $\mathrm{C}$ from spoilage. In our research, $\mathrm{T}_{4}$ (1.5\% citric acid) treatment showed low decrease level of Vitamin $\mathrm{C}$ during storage period. So, treatment $\mathrm{T}_{4}$ was more acceptable than other treatment at $5 \%$ level of significance.

Table 1. The physicochemical properties of minimally processed Indian spinach on day 0 and day 2 due to the effects of different treatments

\begin{tabular}{|c|c|c|c|c|c|c|c|c|c|c|}
\hline & \multicolumn{5}{|c|}{ Day 0} & \multicolumn{5}{|c|}{ Day 2} \\
\hline Treatment & $\begin{array}{c}\text { Firmness } \\
\left(\mathrm{kg} \mathrm{cm}^{-2}\right)\end{array}$ & $\begin{array}{c}\text { TSS } \\
\left({ }^{0} \text { Brix }\right)\end{array}$ & $\begin{array}{c}\text { Vitamin C } \\
\text { (mg/10 g) }\end{array}$ & $\begin{array}{l}\text { TA } \\
(\%)\end{array}$ & pH & $\begin{array}{c}\text { Firmness } \\
\left(\mathrm{kg} \mathrm{cm}^{-2}\right)\end{array}$ & $\begin{array}{c}\text { TSS } \\
\left({ }^{0} \text { Brix }\right)\end{array}$ & $\begin{array}{c}\text { Vitamin C } \\
(\mathrm{mg} / 10 \mathrm{~g})\end{array}$ & ТА (\%) & pH \\
\hline $\mathbf{T}_{0}$ & $16.04 \pm 0$ & $0.40 \pm 0$ & $18.03 \pm 0$ & $20.33 \pm 0$ & $6.77 \pm 0$ & $14.02 \pm 1.25$ & $0.40 \pm 0$ & $11.00 \pm 0.06$ & $16.07 \pm 8.85$ & $5.25 \pm 0.13$ \\
\hline$T_{1}$ & $16.04 \pm 0$ & $0.40 \pm 0$ & $18.03 \pm 0$ & $20.33 \pm 0$ & $6.86 \pm 0$ & $14.01 \pm 1.25$ & $0.40 \pm 0$ & $11.33 \pm 0.06$ & $18.00 \pm 8.85$ & $6.90 \pm 0.13$ \\
\hline $\mathbf{T}_{2}$ & $16.04 \pm 0$ & $0.40 \pm 0$ & $18.03 \pm 0$ & $20.33 \pm 0$ & $6.89 \pm 0$ & $13.47 \pm 1.25$ & $0.40 \pm 0$ & $12.90 \pm 0.06$ & $19.50 \pm 8.85$ & $6.93 \pm 0.13$ \\
\hline $\mathbf{T}_{3}$ & $16.04 \pm 0$ & $0.40 \pm 0$ & $18.03 \pm 0$ & $20.33 \pm 0$ & $6.93 \pm 0$ & $13.02 \pm 1.25$ & $0.50 \pm 0$ & $12.90 \pm 0.06$ & $18.03 \pm 8.85$ & $6.97 \pm 0.13$ \\
\hline $\mathbf{T}_{4}$ & $16.04 \pm 0$ & $0.40 \pm 0$ & $18.03 \pm 0$ & $20.33 \pm 0$ & $5.02 \pm 0$ & $15.45 \pm 1.25$ & $0.30 \pm 0$ & $17.03 \pm 0.06$ & $33.47 \pm 8.85$ & $3.43 \pm 0.13$ \\
\hline $\mathbf{T}_{5}$ & $16.04 \pm 0$ & $0.40 \pm 0$ & $18.03 \pm 0$ & $20.33 \pm 0$ & $5.50 \pm 0$ & $15.02 \pm 1.25$ & $0.30 \pm 0$ & $16.27 \pm 0.06$ & $30.93 \pm 8.85$ & $3.62 \pm 0.13$ \\
\hline $\mathrm{T}_{6}$ & $16.04 \pm 0$ & $0.40 \pm 0$ & $18.03 \pm 0$ & $20.33 \pm 0$ & $5.77 \pm 0$ & $14.56 \pm 1.25$ & $0.40 \pm 0$ & $15.60 \pm 0.06$ & $22.23 \pm 8.85$ & $3.57 \pm 0.13$ \\
\hline $\mathbf{T}_{7}$ & $16.04 \pm 0$ & $0.40 \pm 0$ & $18.03 \pm 0$ & $20.33 \pm 0$ & $6.87 \pm 0$ & $12.57 \pm 1.25$ & $0.60 \pm 0$ & $13.60 \pm 0.06$ & $21.83 \pm 8.85$ & $6.92 \pm 0.13$ \\
\hline $\mathbf{T}_{8}$ & $16.04 \pm 0$ & $0.40 \pm 0$ & $18.03 \pm 0$ & $20.33 \pm 0$ & $6.88 \pm 0$ & $12.03 \pm 1.25$ & $0.50 \pm 0$ & $14.40 \pm 0.06$ & $26.73 \pm 8.85$ & $6.95 \pm 0.13$ \\
\hline $\mathbf{T}_{9}$ & $16.04 \pm 0$ & $0.40 \pm 0$ & $18.03 \pm 0$ & $20.33 \pm 0$ & $6.95 \pm 0$ & $12.01 \pm 1.25$ & $0.50 \pm 0$ & $15.00 \pm 0.06$ & $21.80 \pm 8.85$ & $6.99 \pm 0.13$ \\
\hline $\mathbf{L S D}_{0.05}$ & - & - & - & - & 0.1077 & 1.904 & 0.09329 & 0.4241 & 5.067 & 0.6327 \\
\hline
\end{tabular}

$\left(\mathrm{T}_{1}: 1 \% \mathrm{NaCl}, \mathrm{T}_{2}: 1.5 \% \mathrm{NaCl}, \mathrm{T}_{3}: 2 \% \mathrm{NaCl}, \mathrm{T}_{4}: 1.5 \%\right.$ Citric acid, $\mathrm{T}_{5}: 1 \%$ citric acid, $\mathrm{T}_{6}: 0.5 \%$ citric acid, $\mathrm{T}_{7}: 0.5 \% \mathrm{KMS}, \mathrm{T}_{8}: 1 \%$ $\mathrm{KMS}, \mathrm{T}_{9}: 1.5 \% \mathrm{KMS}$ treatment). Each data point represents the mean of three replicates \pm standard error. 
Table 2. The physicochemical properties of minimally processed Indian spinach on day 4 and day 6 due to the effects of different treatments

\begin{tabular}{|c|c|c|c|c|c|c|c|c|c|c|}
\hline & \multicolumn{5}{|c|}{ Day 4} & \multicolumn{5}{|c|}{ Day 6} \\
\hline Treatment & $\begin{array}{l}\text { Firmness } \\
\left(\mathrm{kg} \mathrm{cm}^{-2}\right)\end{array}$ & $\begin{array}{c}\text { TSS } \\
\left({ }^{0} \text { Brix }\right)\end{array}$ & $\begin{array}{l}\text { Vitamin C } \\
(\mathrm{mg} / 10 \mathrm{~g})\end{array}$ & ТA (\%) & pH & $\begin{array}{l}\text { Firmness } \\
\left(\mathrm{kg} \mathrm{cm}^{-2}\right)\end{array}$ & $\begin{array}{c}\text { TSS } \\
\left({ }^{0} \text { Brix }\right)\end{array}$ & $\begin{array}{l}\text { Vitamin C } \\
\text { (mg/10 g) }\end{array}$ & TA (\%) & pH \\
\hline $\mathbf{T}_{0}$ & $12.02 \pm 0.87$ & $0.50 \pm 0$ & $10.70 \pm 0.05$ & $14.30 \pm 0.23$ & $5.75 \pm 0$ & $9.03 \pm 0.33$ & $0.70 \pm 0$ & $3.60 \pm 0.04$ & $13.83 \pm 0.27$ & $6.00 \pm 0$ \\
\hline $\mathrm{T}_{1}$ & $12.06 \pm 0.87$ & $0.40 \pm 0$ & $11.60 \pm 0.05$ & $14.90 \pm 0.23$ & $6.98 \pm 0$ & $9.57 \pm 0.33$ & $0.60 \pm 0$ & $4.40 \pm 0.04$ & $12.33 \pm 0.27$ & $7.13 \pm 0$ \\
\hline $\mathbf{T}_{2}$ & $11.77 \pm 0.87$ & $0.60 \pm 0$ & $11.90 \pm 0.05$ & $15.53 \pm 0.23$ & $6.98 \pm 0$ & $8.89 \pm 0.33$ & $0.60 \pm 0$ & $5.03 \pm 0.04$ & $12.73 \pm 0.27$ & $7.25 \pm 0$ \\
\hline $\mathbf{T}_{3}$ & $11.29 \pm 0.87$ & $0.40 \pm 0$ & $12.53 \pm 0.05$ & $18.53 \pm 0.23$ & $7.00 \pm 0$ & $8.50 \pm 0.33$ & $0.60 \pm 0$ & $5.66 \pm 0.04$ & $14.47 \pm 0.27$ & $7.27 \pm 0$ \\
\hline $\mathbf{T}_{4}$ & $13.29 \pm 0.87$ & $0.30 \pm 0$ & $16.33 \pm 0.05$ & $22.60 \pm 0.23$ & $3.93 \pm 0$ & 10.6 & $0.40 \pm 0$ & $11.40 \pm 0.04$ & $18.83 \pm 0.27$ & $4.12 \pm 0$ \\
\hline $\mathbf{T}_{5}$ & $13.07 \pm 0.87$ & $0.40 \pm 0$ & $15.70 \pm 0.05$ & $19.93 \pm 0.23$ & $3.94 \pm 0$ & $10.23 \pm 0.33$ & $0.50 \pm 0$ & $10.60 \pm 0.04$ & $15.53 \pm 0.27$ & $4.32 \pm 0$ \\
\hline $\mathbf{T}_{6}$ & $10.33 \pm 0.87$ & $0.50 \pm 0$ & $15.10 \pm 0.05$ & $17.00 \pm 0.23$ & $4.50 \pm 0$ & $10.01 \pm 0.33$ & $0.50 \pm 0$ & $8.39 \pm 0.04$ & $16.97 \pm 0.27$ & $5.90 \pm 0$ \\
\hline $\mathbf{T}_{7}$ & $11.01 \pm 0.87$ & $0.70 \pm 0$ & $13.27 \pm 0.05$ & $18.60 \pm 0.23$ & $6.98 \pm 0$ & $8.33 \pm 0.33$ & $0.56 \pm 0$ & $6.33 \pm 0.04$ & $16.7 \pm 0.27$ & $7.14 \pm 0$ \\
\hline $\mathbf{T}_{8}$ & $10.52 \pm 0.87$ & $0.50 \pm 0$ & $13.90 \pm 0.05$ & $19.03 \pm 0.23$ & $6.97 \pm 0$ & $8.13 \pm 0.33$ & $0.70 \pm 0$ & $7.19 \pm 0.04$ & $16.43 \pm 0.27$ & $7.17 \pm 0$ \\
\hline $\mathbf{T}_{9}$ & $12.44 \pm 0.87$ & $0.60 \pm 0$ & $14.50 \pm 0.05$ & $17.53 \pm 0.23$ & $7.02 \pm 0$ & $7.77 \pm 0.33$ & $0.70 \pm 0$ & $7.99 \pm 0.04$ & $13.97 \pm 0.27$ & $7.27 \pm 0$ \\
\hline $\mathbf{L S D}_{0.05}$ & 1.589 & 0.1523 & 0.3921 & 0.8326 & 0.1077 & 0.9858 & 0.1077 & 0.3613 & 0.8932 & 0.01703 \\
\hline
\end{tabular}

$\left(\mathrm{T}_{1}: 1 \% \mathrm{NaCl}, \mathrm{T}_{2}: 1.5 \% \mathrm{NaCl}, \mathrm{T}_{3}: 2 \% \mathrm{NaCl}, \mathrm{T}_{4}: 1.5 \%\right.$ Citric acid, $\mathrm{T}_{5}: 1 \%$ citric acid, $\mathrm{T}_{6}: 0.5 \%$ citric acid, $\mathrm{T}_{7}: 0.5 \% \mathrm{KMS}, \mathrm{T}_{8}: 1 \%$ $\mathrm{KMS}, \mathrm{T}_{9}: 1.5 \% \mathrm{KMS}$ treatment). Each data point represents the mean of three replicates \pm standard error.

\section{Effect of treatments on $\mathrm{pH}$}

In the minimally processed Indian spinach, the average $\mathrm{pH}$ ranged from 7.1 to 3.9 during different storage periods (Tables 1 and 2); $\mathrm{pH}$ increased with increasing storage period. There was significant difference in $\mathrm{pH}$ at $p=0.05$ among all treatments due to the effect of citric acid, $\mathrm{NaCl}$ and $\mathrm{KMS}$ treatments. At 0 days, $\mathrm{T}_{9}$ attained the highest score (6.95) but treatment $\mathrm{T}_{4}$ got the lowest score (5.02) (Table 1). At 2 days, $\mathrm{T}_{9}$ attained the highest score (6.99) but treatment $\mathrm{T}_{4}$ got the lowest score (3.43) (Table 1). At 4 days, treatment $T_{9}$ attained the highest score (7.02) and treatment $\mathrm{T}_{4}$ got the lowest score (3.93). At 6 days, treatments $T_{3}$ and $T_{9}$ got the highest score (7.27) and treatment $\mathrm{T}_{4}$ got the lowest score (4.12) (Table 2).

The $\mathrm{pH}$ depends on the total quantity of acids as well as the strength of the acids present (Schmidl and Labuza, 2000). According to Daranagama et al., (2012), minimally processed banana pre-treated with ascorbic acid and citric acid stored at 5-7 ${ }^{\circ} \mathrm{C}$ showed slight increase of $\mathrm{pH}$ (lower acidity) after 7 days of storage. High content of $\mathrm{pH}$ diminishes the quality of vegetables. In our research, $\mathrm{pH}$ content was low in $\mathrm{T}_{4}$ since Indian spinach is alkaline when raw. So, $T_{4}$ is considered more acceptable treatment for better storage of minimally processed Indian spinach.

\section{Overall effect of treatments on Vitamin C, TA and pH}

According to Hartwig and McDaniel (1995), $\mathrm{pH}$ is inversely related with organic acid and Vitamin C. At low $\mathrm{pH}$, titrable acidity and Vitamin $\mathrm{C}$ content will be high and vice versa. For minimally processed Indian spinach, low $\mathrm{pH}$ holds up good storage and nutrient quality. The results show significant variation for Vitamin $\mathrm{C}$, titrable acidity and $\mathrm{pH}$ with the treatments $\left(\mathrm{T}_{1}: 1 \% \mathrm{NaCl}, \mathrm{T}_{2}: 1.5 \% \mathrm{NaCl}, \mathrm{T}_{3}: 2 \% \mathrm{NaCl}, \mathrm{T}_{4}: 1.5 \%\right.$ Citric acid, $\mathrm{T}_{5}: 1 \%$ Citric acid, $\mathrm{T}_{6}: 0.5 \%$ Citric acid, $\mathrm{T}_{7}$ : $0.5 \% \mathrm{KMS}, \mathrm{T}_{8}: 1 \% \mathrm{KMS}, \mathrm{T}_{9}: 1.5 \% \mathrm{KMS}$ ). Among all treatments, $\mathrm{T}_{4}$ shows the best result for keeping good quality of storage life. In $\mathrm{T}_{4}$, $\mathrm{pH}$ level was $6.99,3.43$ and 4.12 at 2, 4 and 6 days respectively. As $\mathrm{pH}$ is inversely related with Titrable acidity and Vitamin C, treatment $\mathrm{T}_{4}$ contained high ranges of Titrable acidity $(33.47,22.60$ and $18.83 \%)$ and Vitamin $C(17.03,16.33$ and 11.40 $\mathrm{mg} / 10 \mathrm{~g}$ ). Total Soluble Solids (TSS) or sugar contents remain low in vegetables. In $\mathrm{T}_{4}$ treatment, TSS level $\left(0.30,0.30\right.$ and $\left.0.40{ }^{\circ} \mathrm{Brix}\right)$ was also low. The physical changes (weight loss and firmness) were also at acceptable levels in $\mathrm{T}_{4}$ treatment. It is thus revealed that $\mathrm{T}_{4}(1.5 \%$ Citric acid) treatment is more acceptable for long storage periods and keeping good quality of minimally processed Indian spinach.

\section{Conclusion}

This study revealed a significant effect of treatments on physical and chemical properties of minimally processed Indian spinach. Indian spinach, treated with $1.5 \%$ citric acid, showed a longer shelf life. KMS treatment also showed good result in processed Indian spinach. But from the storage point of view, $\mathrm{T}_{4}(1.5 \%$ citric acid) may be accepted as it contains higher amount of Vitamin C, low pH, low TSS and higher TA than other treatments. Further studies may include detailed analysis of physicochemical properties of minimally processed Indian spinach.

\section{References}

Ahvenainen, R. 1996. New approaches in improving the shelf life of minimally processed fruits and vegetables. Trends in Food Science and Technology, 7: 179-186. https://doi.org/10.1016/0924-2244(96)10022-4

Anthony, S., Abeywickrama, K. and Wijeratnam, W.S. 2003. The effect of spraying essential oils of Cymbopogonnardus, C. flexuosus and Ocimumbasilicum on postharvest diseases and storage life of Embul banana. Journal of Horticultural Science and Biotechnology, 21: 211-216.

AOAC. 1995. Association of Official Analytical Chemists- AOAC, Official methods of analysis, $16^{\mathrm{a}}$ edição, Arlington.

BBS. 2016. Statistical Year Book of Bangladesh. Bangladesh Bureau of Statistics. Statistics Division. Ministry of planning. Government of people's Republic of Bangladesh.

Benedetti, B.C., Golinelli, C.C. and Sarantopoulos, C.I.G.L. 2002. Avaliaçãodepimentãominimamenteprocessa doemro delas e tiras, armazenadonastemperaturas de 5 e $10^{\circ} \mathrm{C}$, In: 
CONGRESSOBRASILEIRO DE CIÊNCIA E TECNOLOGIA DE ALIMENTOS., Porto Alegre: SBCTA, 18: 1241-1245.

Ben-Yehoshua, S., Beaudry R.M., Sjayanty S. and Mir N. 2005. Modified atmosphere packaging and controlled atmosphere storage. In: Ben-Yehoshua S (editor), Environmentally friendly technologies for Agriculture Produce quality. Boca Raton, FL: Taylor and Francis, 3: 61-113.

Chitarra, M.I.F. 1999. Processamentomínimo de frutas e hortaliças, Tecnologia e Treinamento Agropecuário, 2: 7.

Cortez-Vega, Renzo, W., Becerra-Prado, M.A., Soares, M.J., Fonseca, G.G. 2008. Effect of L-Ascorbic acid and Sodium Metabisulfite in the Inhibition of the Enzymatic Browning of Minimally Processed Apple, 3(3):196-201.

Daranagama, A., Ediriweera, S. and Abeywickrama, K. 2012. Pretreatments and cold storage on the quality of minimally processed Ambarella (Spondiasdulcis L.) and the mixed load of Ambarella and pineapple (Ananascomosus (L.) Merr). Journal of Science of University of Kelaniya, 7: 2141. https://doi.org/10.4038/josuk.v7i0.4433

Economos, C.W.D. and Clay, W.D. 1999. Nutritionaland health benefits of citrus fruits. Food, Nutrition and Agriculture, 20/05/2003-23/05/2003 (Havana, Cuba), 24: 8-11.

Ekanayake, A.H. 2014. Pretreatments in managing microorganisms and browning in minimally processed Immature Jackfruit (Polos). B.Sc. Dissertation, Department of Botany, Faculty of Science, University of Kelaniya, Sri Lanka. pp58.

Girardi, C.L., Corrent, A.R., Lucchetta, L., Zanuzo, M.R., Brackmann A., Twyman, Nora, F.R., Nora, L., Silva, J.A. and Rombaldi, C.V. 2005. Effect of ethylene intermittent warming and controlled atmosphere on postharvest quality and the occurrence of woolliness in peach (Prunuspersica cv. Chirip a) during cold storage, Postharvest. Boil. Tec., 38: 25-33. https://doi.org/10.1016/j.postharvbio.2005.05.007

Hartwig, P. and McDaniel, M.R. 1995. Flavor characteristics of lactic, malic, citric and acetic acid mixtures at various $\mathrm{PH}$ levels. Journal of Food science, 60: 384-388. https://doi.org/10.1111/j.1365-2621.1995.tb05678.x

Hassan, M.K. 2006. Final Report: Postharvest loss Assessment: A Study to Formulate Policy for Postharvest Loss Reduction of fruits and Vegetables and Socio-Economic Uplift of the Stakeholders. pp. 188.

Kays, S.J. and Paull R.E. 2004. Stess in harvested products. In: S.J. Kays and R.E. Paull (eds.). Postharvest Biology. Exon Press, Athens, GA. 355-414.

Pirovani, M.E., Piagentini, A.M., Güemes, D.R. and Di Pentima, J.H. 1998.Quality of minimally processed lettuce as influenced by packaging and chemical treatments. Journal of Food Quality, 22: 475- 484 . https://doi.org/10.1111/j.1745-4557.1998.tb00537.x

Pregnolatto, W. and Pregnolatto, N.P. 1985. Normasanalíticas do Instituto Adolfo Lutz: métodosquímiCiênc. Tecnol. Aliment., Minimally processed carrot and green pepper.

Raheem, I.M., Saeed, M., Aslam, W.K.H., Shakeel, A., Raza, S.M., and Afzal, F. 2015. Effect of various minimal processing treatments on quality characteristics and nutritional value of spinach. Journal Global Innovation Agricultural Social Science, 3(2-3): 76-83. https://doi.org/10.17957/JGIASS/3.2-3.715

Ranganna, S. 1994. Handbook of Analysis is of Quality Control for Fruit and Vegetables Products. TataMcGraw-Hill Publishing Co. Ltd. New Delhi.

Schmidl, M.K. and Labuza, T.P. 2000. Essentials of functional foods. Aspen Publishers, Inc. USA, 108.

Zagory, D., and Kader, A. 1988. Modified atmosphere packaging of fresh produce. Journal of Food Technology, 42: 70-77. 